\title{
Adaptation and Validation of the Brazilian Version of the Utrecht Work Engagement Scale
}

\author{
Ana Clandia Souza Vazquez - Universidade Federal de Ciências da Saúde, Rio Grande do Sul, Porto Alegre, Brasil \\ Emilia dos Santos Magnan - Universidade Federal de Ciências da Saúde, Rio Grande do Sul, Porto Alegre, Brasil \\ Juliana Cerentini Pacico - Universidade Federal do Rio Grande do Sul, Rio Grande do Sul, Porto Alegre, Brasil \\ Claudio Simon Hutz - Universidade Federal do Rio Grande do Sul, Rio Grande do Sul, Porto Alegre, Brasil \\ Wilmar B. Schaufeli - Universidade de Utrecht, Utrecht, Holland
}

\begin{abstract}
Engagement at work is a positive mental and dispositional state characterized by Vigor, Dedication and Concentration. The aim of this study was to adapt and get evidence of validity for the Brazilian version of the utrecht work engagement scale (UWES). Participated in the study 1167 workers between 18 and 70 years $(M=36.8, S D=10.3)$ in the Brazilian regions. Studies to establish content and construct validity with the 17- item and the 9-item scales were performed. Exploratory and confirmatory factor analyzes showed that the best solution is unifactorial. Internal consistency was high. Age differences in engagement were found. The results also indicate that the present version of UWES is valid for use in Brazil and reinforce the idea that engagement at work is a universal construct. Although most of the results agree with the findings reported in the literature, some cultural differences appeared and they are discussed in this paper.

Keyword: Work engagement, Positive Psychology, test validation, psychological assessment.
\end{abstract}

\section{Adaptação e Validação da Versão Brasileira da Utrecht Work Engagement Scale}

\begin{abstract}
Resumo
Engajamento no trabalho é um estado mental e disposicional positivo caracterizado por Vigor, Dedicação e Concentração. O objetivo desse estudo foi adaptar e obter evidências de validade da versão brasileira da Utrecht Work. Engagement Scale (UWES). Participaram da pesquisa 1167 trabalhadores, entre 18 e 70 anos $(M=36,8, \mathrm{DP}=10,3)$ nas 5 regiões do Brasil. Foram realizados estudos para estabelecer validade de conteúdo e validade de construto com os 17 itens da escala e os 9 itens da versão reduzida. Análises fatoriais exploratória e confirmatória demonstraram que a melhor solução seria unifatorial. A consistência interna foi elevada. Foram encontradas diferenças de engajamento em relação à idade. Os resultados indicam que a versão brasileira da UWES é válida e reforçam a ideia de que o engajamento no trabalho é um construto universal. Porém, algumas diferenças culturais foram detectadas e são discutidas no presente trabalho.

Palavras-chave: Engajamento no trabalho, Psicologia Positiva, validade de teste, avaliação psicológica.
\end{abstract}

\section{Adaptación y Validación de la Versión Brasileña de la Utrecht Work Engagement Scale}

\begin{abstract}
Resumen
Compromiso en el trabajo es un estado mental y de disposición positiva que se caracteriza por Vigor, Dedicación y Concentración. El objetivo de este estudio fue adaptar y obtener evidencias de validez de la versión brasileña del utrecht work engagement scale (UWES). Participaron del estudio 1167 trabajadores entre 18 y 70 años $(M=36.8, D P=10.3)$ en las 5 regiones de Brasil. Fueron realizados estudios para establecer la validez de contenido y la validez del constructo con los 17 ítems de la escala y los 9 ítems de la versión reducida. Análisis factoriales exploratorio y confirmatorio demostraron que la mejor solución sería unifactorial. La consistencia interna fue alta. Fueron encontradas diferencias de compromiso con relación a la edad. Los resultados indican que la versión brasileña del UWES es válida y corroboran la idea de que el compromiso en el trabajo es un constructo universal. Sin embargo, se encontraron algunas diferencias culturales que son analizadas en este documento.

Palabras clave: Compromiso en el trabajo, psicología positiva, validación de test, evaluación psicológica.
\end{abstract}

\section{Introduction}

The construct of engagement is defined by Schaufeli, Salanova, González-Romá and Bakker (2002) as a mental and dispositional state of energy investment, coping with difficulties and directing the effort to work with which the individual identifies and feels high pleasure to perform. This is not a momentary sensation; engagement at work is a positive, pervasive and persistent mental state. In other words, the engaged individual is one who is full of energy, feel great pleasure and inspiration for what he does and is fully dedicated to his work (Albrecht, 2010; Bakker, 2005; Csikszentmihalyi, 1996; Schaufelli \& Bakker 2010; Xanthoupolou, Bakker, Demerouti, \& Schaufeli, 2009).

In this approach, engagement at work is always analyzed from the perspective of Positive Psychology by the theoretical model Job Demand Resources (JDR-WE). This model takes the perspective of Positive Organizational Psychology, in which the well-being of worker 
is the result of the optimal balance between positive aspects (resources) and negative aspects (demands) of the job characteristics (Schaufeli \& Taris, 2014). It is emphasized that, in JDR-WE model, resources and work demands are not restricted to specific activities or organizations. Work demands are physical, psychological, social and organizational requirements that require effort and are associated with potential risks and physiological and psychological costs (such as mental fatigue, overload, etc.). Labor resources, in turn, act as protective factors that keep people healthy while dealing with the demands of their working life.

There is robust empirical evidence of the theoretical model JDR-WE. For the scope of this paper, it is sufficient to observe the findings that support that engagement characterizes the optimal functioning of the working individual and that it has a central role as mediator of the resources that positively influence people at work (Hakanen, Schaufeli, \& Ahova, 2008; Hallberg \& Schaufeli 2006; Schaufeli \& Bakker, 2004). In this sense is that job resources relate to the engagement and have motivational potential to lead to high performance and to a sense of well-being (Korunka, Kubicek, Schaufeli, \& Hoonakker, 2009; Reijseger, Schaufeli, Peters, \& Taris, 2012).

Studies of engagement at work in this theoretical line demonstrated its positive correlation with attitudes such as organizational commitment (Hakanenet al., 2008) and negative with the intent of leaving of the organization by the employee (Schaufeli \& Bakker, 2004). There are studies that indicate possible correlations between engagement at work and topics such as absenteeism, customer satisfaction, high performance and financial return, among others (Hakanen, Perhoniemi, \& Toppinen-Tanner, 2008; Halbesleben \& Wheeler, 2008; Salanova, Agut, \& Peiró, 2005). Finally, Ouweneel, Leblanc and Schaufeli (2013) demonstrated the positive effect of interventions for people with low engagement in the work that led to the increase of positive emotions and sense of self-efficacy at work.

For several reasons, the theme of engagement at work has been gaining notoriety in contemporary academic studies and practice in the context of work organizations (Schaufeli, 2013). In international and crosscultural research, the Utrechet Work Engagement Scale (UWES) is the instrument of measurement of engagement at work most used, with evidence of validity in more than 10 countries. This research aims to adapt and to obtain evidences of validity of the Brazilian version of UWES. The increases observed in international studies and the consensus among researchers that UWES is an appropriate and efficient solution for measurement of engagement at work give support to the theoretical proposition of this research.

\section{The Construct}

According to Schaufeli (2013), engagement is a construct of a cognitive-affective nature that represents the specific connection of the individual with the work he does and gives him well-being and a sense of fulfillment. Schaufeli and Salanova (2011) argue, even, that engagement is not characterized by the link of the worker with some particular object in their work activities such as the organization or tasks to be performed. This aspect is important because it differentiates engagement at work from other concepts traditionally studied in the field of Organizational and Work Psychology. Hallberg and Schaufeli (2006) investigated the discriminant validity between the constructs 'engagement at work, organizational commitment' and 'job involvement'. The results showed around $12 \%$ to $21 \%$ of shared variance in relation to health complaints and work factors. The distinctive and non-redundant nature of the three constructs was clearly demonstrated by confirmatory factor analysis conducted with the constructs separately $\left[\chi^{2}(227)=422.69, p<.001\right.$, root mean square error of approximation (RMSEA) $=.07$, standardized root mean square residual (SRMR) $=.07$ and comparative fit index $(\mathrm{CFI})=.97]$. The study also shows that only engagement at work had high positive correlations with aspects of health (lack of complaints), fulfillment and well-being of the workers. Their findings highlight conceptual and structural differences of engagement at work in relation to the other constructs. This means that engagement at work, organizational commitment and job involvement are not synonymous with each other, and should not be treated as redundant concepts. Furthermore, it is necessary to differentiate the construct of engagement at work instrumentalized by UWES from that which is traditionally operationalized in studies about Burnout. We believe that one of the main contributions of Schaufeli et al. (2002) is the proposition of a new analytical perspective to the topic of health and well-being at work. Based on Positive Psychology, their proposal broadens the adopted view of engagement at work as a direct opposite of Burnout (Maslach \& Leiter, 1997).

In the traditional perspective, Burnout and engagement at work are understood as a continuum of opposites, Burnout being an erosion of engagement at work. If 
that were true, it would suffice to measure the burnout to identify its effect on engagement at work. Even in theoretical agreement with the idea that engagement at work is a positive antithesis of burnout, Schaufeli et al (2002) demonstrate that they are independent constructs, with different structures that explain different aspects of the relationship of the individual with work. This means that not to feel exhausted at work does not correspond directly to be engaged in it, or vice versa. In fact, recent studies have shown that engagement and burnout may occur concomitantly to some extent (Schaufeli \& Salanova, 2011). Schaufeli et al. (2002) argue, therefore, that engagement at work should be measured with a specific instrument and analyzed from the perspective of a balance between protective factors and potential risk factors that may cause loss and damage to the well-being, performance, and worker health.

\section{Utrecht Work Engagement Scale}

The utrecht work engagement scale (UWES), composed by 17 items, was developed to measure engagement at work using three factors: Vigor, Dedication, and Concentration. According to Schaufeli et al. (2002), the UWES-17 presented an $\alpha=.80$ for Vigor, $\alpha=.89$ for Dedication, and $\alpha=.72$ for Concentration. A high correlation was found between the factors $(r=$ .70), especially between Vigor and Concentration $(r>$ .90 for latent variables and $r>.70$ for observable variables). The reduced version of the scale with 9 items, was tested by Schaufeli, Bakker and Salanova (2006) in a cross-cultural study in 10 countries $(N=14,521)$. The internal consistency of the UWES- 9 had $\alpha$ s between .85 e $.92(M=.92)$, and $r>.90$ between factors (except in France, where $r=.83$ ). The psychometric quality of UWES-9 was corroborated also by the study by Balducci, Fraccanoli and Schaufeli (2010).

Differences were found in engagement at work in terms of age, sex and occupational groups. Schaufeli and Bakker (2004) described that their findings indicate a slight increase of engagement at work with age, but the correlation proved to be weak $(r<.20)$. As for the differences between men and women, Schaufeli, Bakker and Salanova (2006) highlight the misconception to analyze them unless the effect size is calculated (Cohen, 1998). In the 10 countries, the authors found $d$ $<.20$ and considered the differences between men and women as non-important. Relations between engagement at work and occupational group were significant, notably for high levels in Vigor and Dedication of Educators ( $M=4.41$ and $M=4.40$, respectively), Managers
( $M=4.40$ and $M=4.48$, respectively) and Police Officers $(\mathrm{M}=4.14$ and $M=4.55$, respectively).

From a semantic and content point of view, the three factors measured by UWES are defined as follows: Vigor refers to the energy expended in work activity considering the difficulties faced daily. This dimension assesses the willingness and the degree of investment of the individual to make efforts at work, in a persistent manner. The Dedication dimension assesses the sense of significance, enthusiasm, inspiration, pride and challenge the individual attaches to the work he does. It is emphasized here that this dimension can not be explained only as a strong identification with the work. In this sense, Dedication has a deeper scope because it includes an affective component along with the cognitive process of bonding of the individual with work. It also should not be considered as redundant to the job involvement concept. More than being involved, Dedication refers to a particularly strong cognitive-affective connection with work that causes the person to have performance better than expected. Concentration relates to the feeling of being completely immersed and deeply absorbed in his work, in a pleasurable and challenging way. It is similar to the state of flow (Csikszentmihalyi, 1996), characterized as an optimal experience of concentration that does not require effort of the person to be attentive to work.

Moreover, the multidimensionality of UWES-17 and UWES-9 has been investigated in several studies. Originally, Schaufeli et al. (2002) based the three-factor solution in qualitative and quantitative research conducted, based on the state of the art studies in Burnout and engagement at work. Several researchers accepted this solution as appropriate (Agarwal, 2013; Chutghtai \& Buckley, 2012). On the other hand, most international studies indicate that a single factor solution is best, even if the three subscales be considered as subfactors within this general factor (Argawal, 2014; Federici \& Skaalvik, 2011; Hakanen et al., 2008; Mauno, Kinnunen, \& Ruokolainen, 2007; Weigl et al., 2010). Hallberg and Schaufeli (2006) show data that support both solutions, uni-or tri-factorial and defend the idea that the one-factor solution should be used for the most comprehensive investigations of engagement at work and the three-factor solution for a detailed analysis of these constructs compared to other.

In view to what has been stated in this section, the present paper aims to contribute to the studies on engagement at work through the adaptation and validation of the Brazilian version of UWES. 


\section{Method}

\section{Participants}

The participants in the research were 1,167 workers, $35 \%$ male and $65 \%$ female, aged 18 to 70 years $(M=$ 36.8 years, $S D=10.3)$. The sample can be characterized as a convenience sample. Participation was voluntary and anonymous. Most participants $(60 \%)$ had a university degree. They finished an undergraduate program $(n$ $=304)$ or a graduate program $(n=415)$. Almost $34 \%$ only finished high school or some technical school. The others had only basic school or less but all could write and read. The sample consisted of participants from the five Brazilian regions, with $64.8 \%$ from the South, $21.8 \%$ from the Southeast, $7.6 \%$ from the Midwest, $3.6 \%$ from the Northeast, and $1.3 \%$ from the North. Table 1 summarizes the characteristics of the relationship of the participants with their place of work and the level of decision in the functions they exercised at the time of data collection.

In general, it is observed that most workers have formal ties with their jobs and that they work in operational or technical functions (blue-collar workers). At the same time, the sample represents different levels of autonomy in decision making at work similar to the structure of work organizations in Brazil. Volunteer work in nonprofit organizations was highlighted in the sample based on the findings of studies of the literature of the area (Schaufeli et al., 2002). Other variables were analyzed in relation to work, such as weekly hours and average family income. In general, $51,9 \%$ informed that they work less than 44 hours per week. Mean family income ranged in minimum wage (SM) from: up to $1 S M(4.0 \%, N=47), 5 S M(43.2 \%$, $N=510), 10 S M(25.6 \%, N=302)$ more than $10 S M$ $(27.3 \%, N=322)$.
Finally, most participants perform their work activities in private organizations $(N=856,74.2 \%)$; $21.0 \%$ work in government agencies $(N=242)$ and $4.9 \%$ in "mixed capital" organizations (public and private capital) $(N=56)$. About $5.8 \%$ of the participants informed that they also work as volunteers in nonprofit organizations $(N=61)$. The organizations in which workers are inserted professionally operate mostly in the Services sector $(54.1 \%, N=634)$. It is noteworthy that this finding aligns with the reality of the Brazilian market, considering that this is the largest sector in the economy of the country. Moreover, $37.1 \%$ are wholesale and retail trade companies $(N=435)$ and $8.7 \%$ are Industries $(N=102)$. Figure 1 shows the areas of professional activity of the participants.

The participants in this study who work in services companies concentrate more specifically on three occupational groups. Specialized Professional Services, in which they work as liberal professionals or financial advisors, in agribusiness, among others $(N=168)$. Education, from basic education to higher education $(N=130)$. Or professionals in Health $(N=113)$. Already in the Trade sector, participants work primarily in the retail shops $(N=330)$. Finally, the Consumer Goods Industries like footwear, textile, pharmaceutical, construction, etc., represent most companies in this sector $(N=48)$. Some participants also informed participation in Basic Industries in petrochemical, oil and gas, steel, metallurgical and pulp $(n=27)$, and a few others in Intermediate Goods Industries, metalworking $(N=21)$.

Another 107 workers participated in the qualitative study and in the pilot study to validate the content of the preliminary Brazilian version of UWES. Their age varied between 20 and 66 years $(M$ $=34.3, S D=10.81$ ).

Table 1

Sample Characteristics: Education and Relationship with Work Organization

\begin{tabular}{lcc}
\hline Relationship with work organization & $\mathrm{N}$ & $\%$ \\
\hline Formal employment (including government workers) & 915 & 76.2 \\
Autonomous professionals & 101 & 8.4 \\
Owners or entrepreneurs & 90 & 7.5 \\
Trainees, temporary contract or unemployed at the time & 34 & 13.0 \\
Functions performed & $\mathbf{N}$ & $\%$ \\
White Collars Workers (administrative, management) & 130 & 11.8 \\
Blue Collar Workers (profissional, technical and operational) & 934 & 85.2 \\
Voluntary action (non-profit) & 32 & 2.9 \\
\hline
\end{tabular}




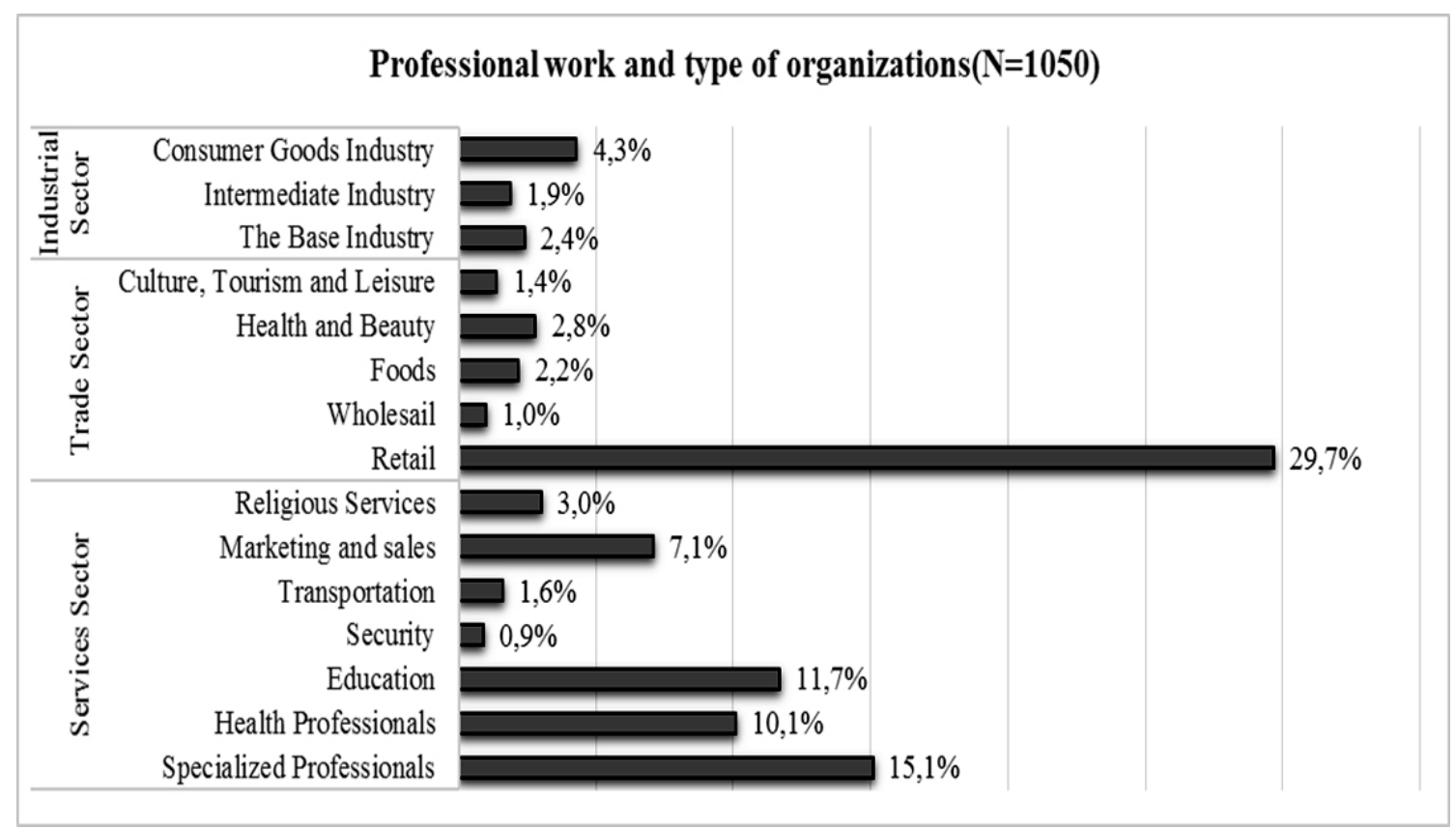

Figure 1. Sample characteristics: areas of operation of the company.

\section{Instruments}

The original version of the Utrecht Work Engagement Scale has17 items that are scored on a 7-point Likert scale indicating the frequency with which engagement at work happens in the situations described in each item ( 0 indicates "never" and 6 "always"). The factors Vigor and Concentration have six items each and the factor Dedication has 5 items. The final score of the Engagement at work corresponds to the sum of the scores on the three factors. The UWES original version for workers presented an internal consistency (alpha coefficient) of .80 for Vigor, .91 for Dedication and .78 for Concentration. The factors also presented high correlations among themselves in Schaufeli et al. (2002) research, which found a mean $r>.60$.

\section{Procedure - Content Validity}

To determine the content validity of the Brazilian version of the UWES 3 focus groups were conducted with 12 participants. The groups were divided by level of education. The first was formed by post-graduate professionals with academic activity and scientific research $(n=3)$. The second, by professionals who had completed higher education and / or high school $(n=$ $5)$. Finally, the third, by professionals with primary or incomplete primary education $(n=4)$.
The focus group participants were asked to read the items and inform about their understanding of them. Then they were asked to report on what they understood as 'engagement at work' and how much the Brazilian version of UWES evaluate this phenomenon, in their view. Data were collected until no new response arose or they started to become redundant, following the criterion of theoretical saturation (Berg, 2001). Participants suggested adaptations only in the writing of the items, to make them easier to understand. No new dimensions or items were added to the Brazilian version of the scale.

\section{Procedure - Translation and Adaptation}

A bilingual academic with expertise in the area translated the 17 items of the original scale. He was instructed to keep the conceptual similarity of the items in the translation process in order to maximize the equivalence between the original and the Brazilian version (Jeanrie \& Bertrand, 1999). The translation was reviewed by four Brazilian judges, fluent in English, with expertise in psychometrics and Organizational and Work Psychology. Adjustments made by the reviewers to make the sentences closest to Brazilian Portuguese, as recommended by the International Test Commission's Guideline (2010). Only item 15 was modified in order to maintain its original meaning in the Brazilian version. 
Judges considered that the original version of this item (At my job, I am very resilient, mentally) was ambiguous. The participants of a focus group demonstrate skewed understanding of the term 'resilient'. Therefore, the item was adapted to "I can adapt to tough situations at work".

The adapted version went through back translation, performed by a bilingual academic with knowledge of the construct. Finally, the Brazilian version translated into English was compared with the original UWES by one of its authors. No significant changes were made, but some items were adjusted to characterize more fully the aspects related to the dimensions Vigor (items 4 and 12) and Concentration (item 14). Item 15 was again changed to "I can mentally adapt to difficult situations at work" so the mental aspect was covered adequately in the sentence. The back translation procedure and the analysis of the similarities between the original and the translated version provided important equivalence data (Van de Vijver \& Hambleton, 1996). No new items or categories were added to the original UWES from the qualitative study carried out. Finally, to analyze the adequacy of the 17 items and the instructions for performing the test in the Brazilian version, a pilot study was conducted. The 95 participants of this study had the same characteristics of the sample of the main research for the adaptation and validation of the Brazilian version of the UWES.

\section{Procedure - Data Collection}

At first, the Brazilian version of the scale was applied in an online survey using the tool SurveyMonkey. The application period was from December 2013 to March 2014. In this stage, 718 workers participated. Next, the scale was administered to 449 workers contacted personally by the research team. In this stage, the data were collected in a single day. It took about 15 minutes to complete the questionnaire. All participants were informed about the objectives of the research and its importance, and that the participation was voluntary and that all the information would be confidential. They also signed an informed consent form.

\section{Results}

A factor analysis with Oblimin rotation was performed with the 17 items of the UWES. The KaiserMeyer-Olkin (KMO) index was adequate and the Barlett sphericity test was significant. Differently than expected, the factor analysis extracted a single factor, as can be seen in Figure 2. When a three-factor solution was forced, eingenvalues for the second and third factors were less than 1.0.

The alpha coefficient of the UWES-17 was $\alpha$ $=.95$. The explained variance was $58,14 \%$. All items loaded positively (between .26 e .77) and appeared to be suitably intercorrelated. In addition, there was no increase in the alpha coefficient with the removal of any items. Such results point to the maintenance of the 17 items of the scale.

In order to test the indication of the international literature about the reduced version of the scale (Balducci, Fraccanoli, \& Schaufeli, 2010; Schaufeliet al., 2006), the differences between the 17- and the 9- item solutions were analyzed. Means, standard deviations, internal consistency, and other psychometric characteristics are shown in Table 2.

The results show that there are no differences between the psychometric characteristics of the two versions of the scale. The decision to use the short version is recommended if only the psychometric characteristics are taken into account. However, more research is needed to determine if predictive and

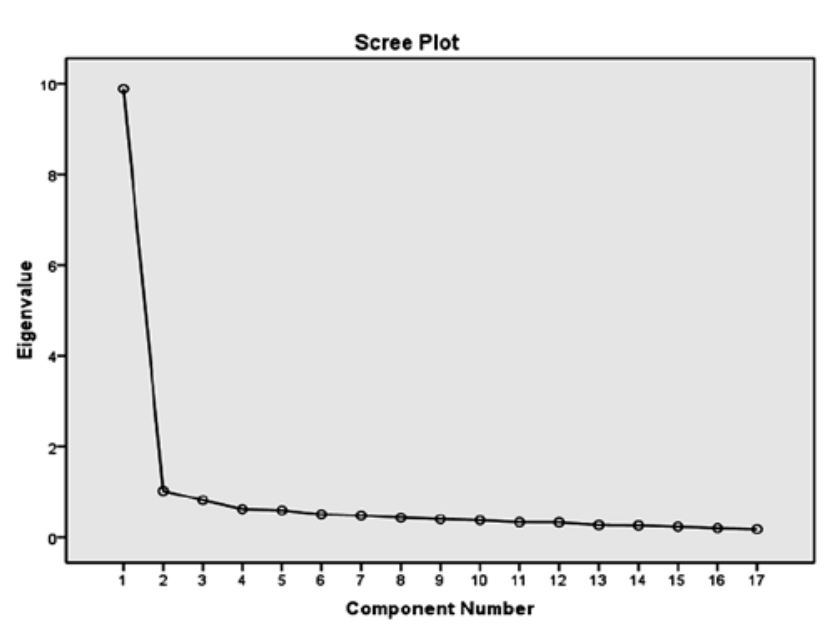

Figure 2. UWES Exploratory factor analysis - scree plot.

Table 2

UWES Psychometric Characteristics with 17 and 9 Items

\begin{tabular}{lcc}
\hline & 17 items & 9 items \\
\hline M (SD) & $4.4(.35)$ & $4.5(.97)$ \\
Alpha coefficient & .95 & .94 \\
Eingenvalue and VAF & $9.88(58.15 \%)$ & $9.51(70.53 \%)$ \\
\hline
\end{tabular}

Psico-USF, Bragança Paulista, v. 20, n. 2, p. 207-217, mai./ago. 2015 
convergent validity and other theoretical questions may not be affected if the short version is used in Brazil. Thus, studies comparing UWES-9 and UWES-17, and their correlations with other variables, must be carried out.

Confirmatory factor analyzes were conducted testing the model with three-factors and one factor. The fit indices are presented in Table 3 . The results suggest that although the three-factor model have slightly better fit indices, the one factor model is more parsimonious and confirms the results found in the exploratory analyzes. However, high correlations between the three factors were found. The Pearson's Correlation between Vigor and Concentration and between Concentration and Dedication was $r=.82$; and between Vigor and Dedication was $r=.81$. This finding shows that they are constructs highly associated, but not redundant. These results will be discussed ahead.

Confirmatory factor analyzes using the reduced version of the scale (nine items) were also performed. Models of one and three factors were tested. Although the fit indices are slightly more appropriate, this does not justify the removal of items, because it would represent a loss of information in favor of a nonsignificant change in model fit. Differences between men and women were also found. These findings are similar to those reported by Schaufeli et al. (2006). The gender difference is small $(d=.23)$ and was not significant within our sample size. Multigroup analyzes were performed to assess the scale invariance between men and women. The model parameters were fixed between the groups considering the invariance of the scale in relation to gender. The results suggest the absence of differential item functioning by gender, with the model with equivalent parameters presenting adjustment $[\mathrm{x}$ ${ }^{2}=1407.34$ (338); RMSEA $=.076(90 \%$ C.I. $=.072$ to $.080)$; CFI $=.97$; TLI $=.98]$.

Sociodemographic and labor variables were also tested to analyze possible differences. As expected, some occupational groups stood out significantly with respect to the high level of engagement at work. The more engaged at work are the White Collar Workers who are in positions of greater autonomy and decision-making at work $(M=5.0, S D=.98)$, followed by professionals who work on a voluntary basis, in nonprofit organizations $(M=4.6, S D=1.27)$. The less engaged at work are the Blue Collar Workers $(M=4.3$, $S D=1.15$ ), who perform operational functions that are more restricted to actions of a technical nature. The effect size of the difference between White and Blue Collars is large ( $d=.65)$. On the other hand, professionals working on transportation of people and supplies (drivers, taxi drivers and truckers) present greater engagement at work $(M=4.9, S D=.53)$, followed by Managers $(M=4.7, S D=1.04)$, Educators $(M=4.6, S D$ $=1.02)$, and health professionals $(M=4.2, S D=1.11)$. Post Hoc tests showed that the differences between the highest and lowest levels of engagement at work are significant $(p<.05)$. Moreover, the effect size of the difference between health professionals and those working on transportation $(d=.82)$ is very high (Cohen, 1998). However, the effect size of the differences between transportation professionals and managers $(d$ $=.14)$ or educators $(d=.33)$ is small or medium. The associations between specific occupational groups and engagement at work that were found seem to indicate that autonomy and greater scope in decision making at the work place are important resources for engagement at work. These findings are in line with results reported in other international studies (Balducci, Fraccaroli, \& Schaufeli, 2010; Schaufeli et al., 2006).

However, the findings concerning age were different from what has been reported by other researchers (Balducci, Fraccaroli, \& Schaufeli, 2010; et al., 2006). The average engagement in the work by the Brazilians increases upwardly and it is significant. For this analysis, the participants were grouped by age ranges related to professional careers in general (Veloso, Dutra, \& Nakata, 2008). Between 18 and 28 years, which corresponds to the beginning the working lives, the engagement at work

Table 3

Indices of Adjustment

\begin{tabular}{lccccc}
\hline Model & $\chi^{2}$ & $d f$ & CFI & TLI/NNFI & RMSEA (90\% CI) \\
\hline One fator (17 items) & 1804.00 & 119 & 0.96 & 0.95 & 0.10 \\
Three fator (17 items) & 1667.99 & 122 & 0.96 & 0.95 & 0.10 \\
One fator (9 items) & 633.06 & 63 & 0.98 & 0.97 & 0.13 \\
Three fator (9 items) & 472.79 & 66 & 0.98 & 0.98 & 0.12 \\
\hline
\end{tabular}

Psico-USF, Bragança Paulista, v. 20, n. 2, p. 207-217, mai./ago. 2015 


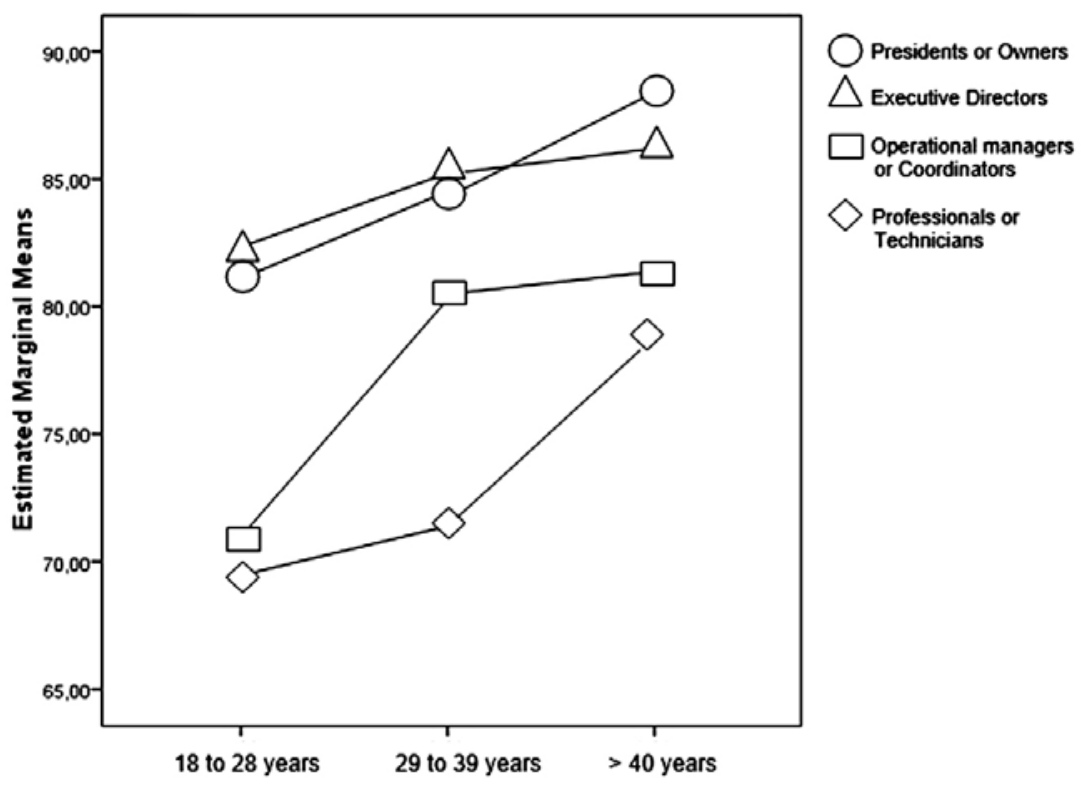

Figure 3. Age, function, and work engagement.

is comparatively lower $(M=4.1, S D=1.23)$ than for those between 29 e 39 years, when they are in training of the professional careers $(M=4.4, \mathrm{SD}=1.04)$ and above 40 years, in the consolidation of the professional careers $(M=4.7, S D=1.10)$. This finding stood out against two other aspects that have proved significant in the analysis: marital status and job function.

Brazilians who are married $(M=4.5, S D=1.13)$, separated $(M=4.6, S D=1.09)$ and widowers $(M=4.5$, $S D=1.08)$ present higher means in work engagement than those who are single $(M=4.3, S D=1.17)$. In addition, those who work as presidents or owners $(M$ $=5.0, S D=1.16)$ or executive directors $(M=5.0, S D$ $=.80$ ) of the company, present higher engagement in work means than those who are in functions of a more operational nature, such as coordinators and operational managers $(M=4.6, S D=1.09)$ or professionals and technicians $(M=4.2, S D=1.16)$. However, these differences are mediated by age. Nevertheless, when age differences are controlled, they disappear, as can be seen in Figure 3. Although it was not expected, the influence of age in engagement at work is characterized as an important variable to understand its phenomenon in Brazilian workers.

\section{Final Considerations}

The results of the studies to adapt the Utrecht Work Engagement Scale to measure work engagement in Brazilians show good evidence of content and construct validity for use in our cultural context. Data from the validation studies of the Brazilian version of the UWES strengthen the indication that engagement at work is a construct that can be universal in its definition. However, the results also show that there are some cultural differences that are important and that deserve to be taken into account.

First, a single factor was extracted from the exploratory analyzes. The indices of adjustment were adequate and the residuals are acceptable. This solution is corroborated by some international studies and may have been found because engagement, as measured by UWES, is a construct with high correlation between items (Agarwal, 2014; Chutghtai \& Buckley, 2013; Federici \& Skaalvik, 2011; Hakanenet al., 2008; Mauno et al., 2007; Weigl et al., 2010). In Brazil, the psychometric analysis of the scale confirms a one-factor solution as more parsimonious both for the UWES-17 as for the UWES-9. However, it is also possible to use the three-factor solution, if it is important to a theoretical analysis or to compare results with international studies. Exploratory and confirmatory analysis presented different results that seem to be opposites; however, both solutions are appropriate in some way. Schaufeli and Bakker (2010) argued that is very common that when conducting confirmatory factor analysis, a three-factor solution may not be clear but still fits as a possible model to interpret the engagement results. In conclusion, the 
application of the one-factor or three-factor model has to be based on the theoretical objective of the measurement of work engagement using UWES. Therefore, the decision is between a global interpretation of the work engagement process (one-factor) or a specific and deeper comprehension of the internal dynamic of the work engagement process (three-factors).

In second place, we must evaluate the implications of the indication for the use of the reduced version of the scale, as there is no psychometric differences between the Brazilian versions of the UWES-17 and UWES-9. This result is consistent with the international literature (Balducci, Fraccanoli, \& Schaufeli, 2010; Schaufeliet al., 2006). However, the Brazilian version of UWES still lacks studies of convergent and predictive validity comparing the scale of 17 items with the scale of 9 items. This is crucial for decision making about which version is more appropriate to measure engagement at work without running the risk of losses in validity if the reduced version of the scale is used.

Finally, and perhaps the original contribution of this paper, the results demonstrate the interaction of age with increasing engagement of Brazilians at work. As expected, the results showed no significant associations of engagement in work with specific aspects of organizations or activities such as type of company or sector of operation. Differences that were significant, such as marital status and function performed, covaried with age. This aspect deserves attention in Brazilian studies on engagement at work because it reflects cultural differences in the construct for our population. We consider that, possibly, this result is linked to the labor market in Brazil and how the professional careers of Brazilians are structured. The significant relationship found between engagement at work and certain occupational groups, which showed a greater autonomy in conducting its activities, also seems to indicate this line of interpretation. It is important to conduct future studies to investigate these findings in greater depth.

It is important to note some limitations of this research for the generalization of its results. The sample was predominantly female, even though data have been obtained from different functions, businesses, and social classes. Further studies should be conducted to improve the representation of gender and sex in the workplace. Furthermore, although this research has received responses from participants in the 5 Brazilian regions, data are significantly concentrated in the South and Southeast regions. New studies should be conducted to better understand how Brazilians in different regions engage in work.

\section{References}

Albrecht, S. (2010). The handbook of employee engagement: Perspectives, issues, research and practice. Northampton, MA: Edwin Elgar.

Agarwal, U. A. (2014). Linking justice, trust and innovative work behavior to work engagement. Personnel Review, 43(1), 41-73.

Bakker, A. B. (2005). Flow among music teachers and their students: The crossover of peak experiences. Journal of Vocational Behavior, 66(1), 26-44.

Balducci, C., Fraccaroli, F., \& Schaufeli, W. B. (2010). Psychometric properties of the Italian version of the Utrecht Work Engagement Scale (UWES-9): A cross-cultural analysis. European Journal of Psychological Assessment, 26,143-149.

Berg, B. (2001). Qualitative research methods for the social sciences. Boston, MA: Allyn and Bacon.

Chughtai, A. A., \& Buckley, F. (2013). Exploring the impact of trust on research scientists' work engagement: Evidence from Irish science research centers. Personnel Review, 42 (4), 396-421.

Cohen, J. (1998). Statistical power analysis for the behavioral sciences. Hillsdale, NJ: Lawrence Erlbaum Associates.

Csikszentmihalyi, M. (1996) Creativity: Flow and the psychology of discovery and invention. New York: HarperCollins.

Frederici, R. A., \& Skaalvik, E. M. (2011). Principal self-efficacy and work engagement: Assessing a Norwegian principal self-efficacy scale. Social Psychology Educational, 14, 575-600.

Hakanen J., Perhoniemi R., \& Toppinen-Tanner S. (2008). Positive gain spirals at work: From job resources to work engagement, personal initiative and work-unit innovativeness. Journal of Vocational Behavior, 73, 78-91.

Hakanen, J. J., Schaufeli, W. B., \& Ahola, K. (2008). The job demands-resources model: A three-year cross-lagged study of burnout, depression, commitment, and work engagement. Work \& Stress, 22(3), 224-241.

Halbesleben, J. R. B., \& Wheeler, A. R. (2008). The relative roles of engagement and embeddedness in predicting job performance and intention to leave. Work \& Stress, 22, 242-256. 
Hallberg, U. E., \& Schaufeli, W. B. (2006). "Same same" but different. Can work engagement be discriminated from job involvement and organizational commitment? European Psychologist, 11(2), 119-127.

International Test Commission (2010). International Test Commission guidelines for translating and adapting tests. Retrieved from http//www.intestcom.org

Jeanrie, C., \& Bertrand, R. (1999). Translating tests with the international commission's guidelines: Keeping validity in mind. European Journal of Psychological Assessment, 15(3), 227-283.

Korunka, C., Kubicek, B., Schaufeli, W. B., \& Hoonaker, P. (2009). Work engagement and burnout: Testing the robustness of the job demands-resources model. The Journal of Positive Psychology, 4(3), 243-255.

Maslach, C., \& Leiter, M. P. (1997).The truth about burnout: How organizations cause personal stress and what to do about it. San Francisco: Jossey-Bass.

Mauno, S., Kinnunen, U., \& Ruokolainen, M. (2007). Job demands and resources as antecedents of work engagement: A longitudinal study. Journal of Vocational Behavior, 70, 149-171.

Ouweneel, E, LeBlanc, P. M., \& Schaufeli, W. B. (2013). An online positive psychology intervention to promote positive emotions, self-efficacy, and engagement at work. Career Development International, 18(2), 173-195.

Reijseger, G., Schaufeli, W. B., Peters, M. C. W., \& Taris, T. W. (2012). Ready, set, go! A model of the relation between work engagement and performance. In S.P. Gonçalves \& J. G. Neves (Eds.), Occupational health psychology: From burnout to well-being (pp. 289306). Scientific \& academic publishing: USA.

Salanova, M., Agut, S., \& Peiró, J. M. (2005). Linking organizational resources and work engagement to employee performance and customer loyalty: The mediation of service climate. Journal of Applied Psychology, 90(6), 1217-1227.

Schaufeli, W. B. (2013). What is engagement? In C. Truss, K. Alfes, R. Delbridge, A. Shantz \& E. Soane (Eds.), Employee Engagement in Theory and Practice (pp. 3-37). London: Routledge

Schaufeli, M. S., \& Bakker, A. B. (2010). Defining and measuring work engagement: Bringing clarity to the concept. In A. B. Bakker \& M. P. Leiter (Eds.),
Work engagement: $A$ bandbook of essential theory and research (pp.10-24). East Sussex: Psychology press.

Schaufeli, W. B., \& Bakker, A. B. (2004). Job demands, job resources, and their relationship with burnout and engagement: A multi-sample study. Journal of Organizational Behavior, 25, 293-315.

Schaufeli, W. B., Bakker, A. B., \& Salanova, M. (2006). The measurement of work engagement with a short questionnaire: A cross-national study. Educational and Psychological Measurement, 66, 701-716.

Schaufeli, W. B., \& Salanova, M. (2011). Work engagement: On how to better catch a slippery concept. European Journal of Work and Organizational Psychology, 20(1), 39-46.

Schaufeli, W. B., Salanova, M., González-Romá, V., \& Bakker, A. B. (2002). The measurement of engagement and Burnout: A two simple confirmatory factor analytic approach. Journal of Happiness Studies, 30, 71-92.

Schaufeli, W. B; Taris, W. T. (2014). A Critical review of the Job Demands-Resources model: Implications for improving work and health, p. 43-66. In G. F. Bauer \& O. Hämmig (Orgs), Bridging Occupational, Organizational and Public Health: A Transdisciplinary Approach. NY: Springer.

Van de Viejer, F. J. R., \& Hambleton, R. K. (1996). Translating tests: Some practical guidelines. European Psychologist, 1, 89-99.

Veloso, E. F. R., Dutra, J. S., \& Nakata, L. E. (2008). Percepção sobre carreiras inteligentes: Diferenças entre as gerações Y, X e Baby boomers. XXXII Anais do Encontro Nacional de Pesquisa em Administração. Rio de Janeiro: Anpad.

Weigl, M., Hornung, S., Parker, S., Petru, R., Glaser, J., \& Angerer, P. (2010). Work engagement accumulation of task, social, personal resources: A three-wave structural equation model. Journal of Vocational Behavior, 77,140-153.

Xanthopoulou, D., Bakker, A. B., Demerouti, E., \& Schaufeli, W. B. (2009). Work engagement and financial returns: A diary study on the role of job and personal resources. Journal of Organizational and Occupational Psychology, 82, 183-200.

Recebido:15/07/2014 $1^{a}$ reformulação: 08/10/2014 $2^{a}$ reformulação: $21 / 12 / 2014$

Aprovado: 05/02/2015 
Sobre os autores:

Ana Claudia Souza Vazquez é professora da Universidade Federal de Ciências da Saúde de Porto Alegre, Brasil e trabalhou por 15 anos como gerente em diferentes organizações. Suas linhas de pesquisa estão em Psicologia Organizacional e Estratégia positiva.

Emília dos Santos Magnan é psicóloga e membro do grupo de pesquisa em Psicologia Organizacional (UFCSPA).

Juliana Cerentini Pacico é pós-doc no Programa de Pós-Graduação em Psicologia da Universidade Federal do Rio Grande do Sul. Suas linhas de pesquisas estão focadas em Psicologia Positiva, Avaliação Psicológica e Personalidade.

Claudio Simon Hutz é professor titular da Universidade Federal do Rio Grande do Sul. Suas linhas de pesquisa estão focadas em Psicologia Positiva, Avaliação Psicológica e Psicometria e Desenvolvimento Social e da Personalidade.

Wilmar B. Schaufeli é professor de Psicologia Organizacional e do Trabalho da Universidade de Utrecht e consultor sênior de Schouten \& Nelissen. Ele é reconhecido internacionalmente no domínio da saúde ocupacional e tem mais de 300 publicações sobre burnout, vício e envolvimento no trabalho.

Contato com os autores:

Rua Sarmento Leite, 245/sala 208, Porto Alegre - RS

CEP: $90.050-170$

E-mail: anasv@ufcspa.edu.br 
